\title{
In vivo evaluation of antiseptics and disinfectants on control of Caseous Lymphadenitis: clinical, haematological, serological and microbiological monitoring
}

\author{
Avaliação in vivo de antissépticos e desinfetantes no controle da Linfadenite \\ Caseosa: acompanhamento clínico, hematológico, sorológico e microbiológico

\begin{abstract}
Lauana Borges Santiago 1*, Raymundo Rizaldo Pinheiro', Francisco Selmo Fernandes Alves', Vanderlan Warlington Souza dos Santos ${ }^{2}$, Apoliana de Sousa Rodrigues ${ }^{2}$ Ana Milena César Lima², Eduardo Luiz de Oliveira', Fernando Henrique Melo Andrade Rodrigues de Albuquerque ${ }^{1}$
\end{abstract}

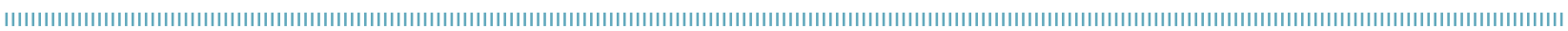

\begin{abstract}
The objective of this experiment was to evaluate the efficacy of iodine tincture at $10 \%$ and sodium hypochlorite at $2.5 \%$ applied into the abscess of animals affected by Caseous Lymphadenitis (CL). Eighteen ewes were used, assorted into three groups: one treated with iodine tincture at 10\% (IT), another one with sodium hypochlorite at $2.5 \%(\mathrm{SH})$ and the last group underwent the conventional treatment (CT). Conventional treatment was based on surgical drainage and chemical cauterization of the lesion with iodine tincture at $10 \%$. Natural rupture of six abscesses from IT group was observed and in five of them the viability of Corynebacterium pseudotuberculosis was confirmed on the lesion place, after rupture of lymph node. As for the $\mathrm{SH}$ group, spontaneous rupture was observed in five out of six abscesses treated, and the microorganism was identified on the lesion of five animals, after rupture. In the sixth animal of this group, abscess involution was noticed. A severe swelling was identified in the region of lymph node treated, resulting in wide lesion in animals from groups IT and SH. No difference ( $p>0,05$ ) was found in blood parameters due to treatments. As for the serological monitoring of animals, comparative analysis between months within each group showed that months $1,2,3$ and 4 were different $(\mathrm{p}<0,05)$ from month 0 , for groups IT and $\mathrm{SH}$. For CT group, there was no difference $(\mathrm{p}>0,05)$ between months 1 to 5 and 0 . Then, the application of iodine tincture at $10 \%$ or sodium hypochlorite at $2.5 \%$ into the abscess of animals affected by CL, at stage in which lesions are detected through inspection, is not effective for its control.
\end{abstract}

KEYWORDS: abscess; Corynebacterium pseudotuberculosis; sheep; treatment.
RESUMO: Objetivou-se com este experimento avaliar a eficácia da tintura de iodo a $10 \%$ e do hipoclorito de sódio a 2,5\% aplicados no interior do abscesso de animais acometidos pela Linfadenite Caseosa (LC). Foram utilizadas 18 fêmeas ovinas, divididas em 3 grupos: o primeiro foi tratado com tintura de iodo a $10 \%$ (TI), o segundo com hipoclorito de sódio a 2,5\% (HS) e o último grupo foi submetido ao tratamento convencional (CT). O tratamento convencional da doença consistia na drenagem e cauterizaçáo química dos abscessos, utilizando-se solução de iodo a 10\%. Foi observada a ruptura natural dos seis abscessos do grupo TI, sendo que em cinco deles a viabilidade do Corynebacterium pseudotuberculosis foi confirmada no local da lesão, após a ruptura do linfonodo. Quanto ao grupo HS, a ruptura espontânea foi observada em cinco dos seis abscessos tratados, sendo o microrganismo identificado na lesão dos cinco animais após o rompimento. No sexto animal desse grupo, foi constatada a involução do abscesso. Foi verificado um edema intenso na regiáo do linfonodo tratado com formação de uma lesão de grande extensão nos animais dos grupos TI e HS. Náo foi detectada diferença $(\mathrm{p}>0,05)$ nos parâmetros hematológicos em decorrência dos tratamentos avaliados. Quanto ao acompanhamento sorológico dos animais, a análise estatística comparativa entre os meses, dentro de cada grupo, mostrou que os meses 1, 2, 3 e 4 foram diferentes $(\mathrm{p}<0,05)$ do mês 0 para os grupos TI e HS. No grupo CT, não houve diferença $(\mathrm{p}>0,05)$ entre os meses de 1 a 5 e o mês 0 . Conclui-se que a aplicaçáo de tintura de iodo a $10 \%$ ou hipoclorito de sódio a $2,5 \%$ no interior do abscesso de animais acometidos pela LC, em estágio no qual as lesóes são detectadas por meio da inspeção, não é eficaz para o seu controle.

PALAVRAS-CHAVE: abscesso; Corynebacterium psendotuberculosis; ovino; tratamento. 


\section{INTRODUCTION}

In recent years, the production of goats and sheep has been representing an important part in the context of Brazilian agribusiness. Currently, it is characterised as a very important cultural, social and economical activity for the Northeast of Brazil, playing a crucial role in the development of this region. The production of high biological value food (milk, meat and offal) and skin of excellent quality, besides the adaptability of animals to local ecosystems, allow the goat and sheep industry to fit as a good alternative for work and income (Moraes Neto et al., 2003). However, there is still a low productivity in the region due to inadequate handling and to frequent occurrence of diseases, like Caseous Lymphadenitis (CL).

$\mathrm{CL}$ is a chronic and debilitating disorder which affects small ruminants, characterised by the formation of abscesses in one or more lymph nodes, caused by Corynebacterium pseudotuberculosis, a positive Gram bacillus, short and irregular, with approximately 0.5 to $0.6 \mu \mathrm{m} \times 1.0$ to $3.0 \mu \mathrm{m}$. It is an infectious disease, which is a worldwide problem, responsible for causing severe economic losses for goat and sheep industry (ALves et al., 2007). The depreciation of skins value, carcass condemnation, falling in production of meat, milk, wool and reproductive efficiency are some of the main damages caused by CL (Krishna et al., 1977; Figueiredo et al., 1982; Paton et al., 1994; Paton et al., 2003), in addition to public health risk posed by the zoonotic potential described for C. pseudotuberculosis (Mills et al., 1997; Peel et al., 1997; Join-Lambert et al., 2006).

The occurrence of injuries on the skin of animals is the main gateway for the microorganism, which is in the environment due to rupture of abscesses of animals infected by the disease (Nairn; Robertson, 1974). The purulent exudate of a CL lesion is extremely rich in viable bacterial cells, with an approximate concentration of $1 \times 10^{6}$ to $5 \times 10^{7}$ cells per gram of material (Brown; Olander, 1987). Therefore, the main aspect related to the control of this illness is the immediate isolation of affected animals and surgical drainage of abscess before its natural rupture, once the microorganism is able to survive and persist in the environment for a long period of time (Williams, 1980). Such characteristic of the microorganism associated with inefficiency of the treatment based on antimicrobial agents and the difficult detection of infected animals make the eradication of CL an extremely arduous task to be performed (Williamson, 2001).

The currently recommended treatment for $\mathrm{CL}$ is drainage and chemical cauterization of abscesses, using iodine solution at $10 \%$, when they are in advanced stage of development. However, this technique represents high risks of environmental contamination, whether through unexpected spontaneous rupture of abscess or by simple exposure to external environment of a highly contaminated material.
An experiment evaluating the application of formaldehyde solution at $10 \%$ into the lymph node has already been accomplished, which found the death of $C$. pseudotuberculosis at the injury place. However, the use of this product inside the abscesses is responsible for the onset of various disorders as the occurrence of fibrosis, necrosis, destruction of epithelial and adjacent muscle tissues, and possible invasion of bone tissue (Alves; Pinheiro, 2003). Moreover, it is known that formaldehyde has teratogenic, mutagenic and carcinogenic effects on laboratory animals, and it is also responsible for causing birth defects and other adverse reactions (UFRGS, 2003).

Recently carried out in vitro studies aiming to evaluate the efficacy of antiseptics and disinfectants of low toxicity to the animal organism against $C$. pseudotuberculosis reported the high sensitivity of this microorganism face to solution of iodine tincture at $10 \%$ and sodium hypochlorite at $2.5 \%$ (Santiago et al., 2010). Therefore, the aim of this experiment was to evaluate the efficacy of these substances inside the abscess of animals affected by CL in early stages of development, focusing on treating and controlling the disease.

\section{MATERIAL AND METHODS}

\section{Experiment location and period}

The experiment was conducted at Embrapa Goats and Sheep (CNPC), located in Sobral, in a semi-arid hinterland of Ceará (Brazil), at $3^{\circ} 41^{\prime} 32^{\prime \prime}$ South latitude and $40^{\circ} 20^{\prime} 53^{\prime \prime}$ West longitude, at an altitude of $75 \mathrm{~m}$. The experiment was conducted between July and December of 2009, in accordance with ethical principles adopted by the National Council for Control of Animal Experimentation (CONCEA), Law no. 11.794, October $8^{\text {th }} 2008$.

\section{Experimental groups}

Eighteen crossbred Santa Ines ewes naturally infected by $\mathrm{CL}$ were used, belonging to CNPC experimental herd. The animals were kept in a paddock of native pasture, had ad libitum access to mineral salt and water and were inspected and selected from clinical presentation of CL in early stage of development. The initial stage of the disease was identified through visible and perceptible enlarged lymph nodes, through the inspection of animals, with absence of alopecia in the affected area. The complete clinical examination, performed before the start of the experiment, did not detect any other pathological finding in animals, except for changes in lymph nodes. All selected animals were tested through the Synergistic Haemolysis Inhibition (SHI) test to confirm diagnosis of $\mathrm{CL}$ and thereafter were randomly assorted into 
three groups, containing six animals each. The first group of animals was treated with iodine tincture at $10 \%$ (IT), the second group was treated with sodium hypochlorite at $2.5 \%$ (SH) and the third group was used as control for the completion of conventional treatment of this disease, through surgical drainage and chemical cauterization of the lesion with iodine tincture at $10 \%(\mathrm{CT})$. For the preparation of the solution of iodine tincture at $10 \%, 100 \mathrm{~g}$ of iodine ressublimate, $60 \mathrm{~g}$ of potassium iodide, $50 \mathrm{~mL}$ of distilled water and $950 \mathrm{~mL}$ of absolute alcohol were used. As for the solution of sodium hypochlorite at $2.5 \%$, a Brilux ${ }^{\circ}$ brand commercial product was used, based on sodium hypochlorite, sodium hydroxide, water and active chlorine content of $2.5 \% \mathrm{w} / \mathrm{w}$. The active chlorine percentage was confirmed using Brazilian Technical Standards Association (ABNT) NBR 9425:2005 (ABNT, 2005. Before treatment, a volume of $1 \mathrm{~mL}$ of sterile saline solution $(\mathrm{NaCl}, 0.95 \%)$ was injected into the involved lymph node and then aspirated for microbiological confirmation of C. pseudotuberculosis.

\section{Treatment and clinical, microbiological and haematological monitoring}

Initially, trichotomy and antisepsis of the region of lymph nodes affected were taken, with alcohol at $70 \%$ and iodine tincture at $10 \%$. A volume of $5 \mathrm{~mL}$ of the product to be tested inside the abscess was applied, using disposable syringes and needles, with $5 \mathrm{~mL}$ and $25 \times 0.7 \mathrm{~mm}$ in diameter, respectively. After treatment, animals were clinically evaluated during five months, twice a week, for describing the development of clinical case. Complete clinical examination (Diffay et al., 2005) was performed, emphasising the characterisation of lesions in lymph nodes, as the increase or decrease in the diameter of abscesses, change in its consistency, sensitivity, mobility, scarring or rupture. In cases of rupture, the material was collected for isolation and identification of the microorganism present in the injured place. After that, the wound was treated with iodine tincture at $10 \%$ and insect repellent spray. When necessary, a healing ointment and a local antibiotic were used. The collected material was plated on blood agar and colonies were subjected to macroscopic characterisation, Gram staining method and catalase, urease and fermentation of carbohydrates tests, for confirmation of C. pseudotuberculosis (CARTER et al., 1986). Variations in volume of abscesses were measured with aid of a digital caliper. For complete blood count, blood samples were collected through puncture of the jugular vein using vacutainer system in $5 \mathrm{~mL}$ tubes containing tetra-acetic ethylenediamine acid anticoagulant 7 days after treatment and at the end of the experiment. Haematology, following the method described by COLES (1993), consisted of the determination of the following parameters: cell volume (microhematocrit method), haemoglobin (cianometahaemoglobin method), total leucocyte count (haemocytometer method) and differential leucocyte count, which were classified as segmented neutrophils, band neutrophils, eosinophils, lymphocytes and monocytes (blood smear). All haematological analyses were done in the Laboratory of Clinical Pathology of CNPC.

\section{Serological monitoring}

Serological monitoring of animals was performed every 15 days, through Serological monitoring (SHI), following the methodology described by KNIGHT (1978). SHI is considered a sensitive, but not specific test for diagnosis of C. pseudotuberculosis. Brown et al. (1987), considering microbiological exam as gold standard test, had shown sensitivity of $90.9 \%$ and specificity of $61 \%$, under field conditions, for SHI test. Blood samples were obtained by puncturing the jugular vein using vacutainer system in $10 \mathrm{~mL}$ tubes without anticoagulant. Blood samples were centrifuged at $3000 \mathrm{rpm}$ for 10 minutes and serum was stored in eppendorf tubes in a freezer at $-20^{\circ} \mathrm{C}$. All microbiological and serological analyses were done in the Laboratory of Bacteriology of CNPC.

\section{Statistical analyses}

A completed randomised experimental design was used, with three treatments and six replications. The data obtained were analysed for their normality by Lilliford's test and subjected to analysis of general variance, using the statistical program SAEG (SAEG, 2007). The averages comparison was performed using Dunnett's test, in which a significance level of $5 \%$ was adopted.

\section{RESULTS AND DISCUSSION}

The evolution of clinical case of each animal belonging to the three groups is shown in Figure 1, considering the diameter of lymph nodes and presence or absence of rupture in the abscesses. Day 0 corresponds to the size of lymph nodes, measured prior to treatments.

For IT and SH groups, it was considered as satisfactory the treatment which promoted involution of abscess or, after spontaneous rupture of the nodule, did not contain viable C. pseudotuberculosis in the lesion. As for the conventional treatment, the efficacy was determined according to the nonoccurrence of unexpected spontaneous rupture of abscess, considering a follow-up of infected animals every three days.

There was a natural rupture of six abscesses treated with iodine tincture at $10 \%$ (Fig. 1A), and in five of them the viability of C. pseudotuberculosis was confirmed at the lesion place, 
after rupture of lymph node. An interesting datum is related to the aspect of the material collected after rupture. All abscesses treated with iodine tincture at $10 \%$ contained a fibrinous material inside it, encapsulated, firm in consistency and far adhered to the adjacent musculature, formed after the completion of the treatment. In this material, C. pseudotuberculosis was not confirmed in any animal. However, in five animals of this group, the caseous material typically observed in abscesses of animals affected by the CL was also present in the lesion. From this

A
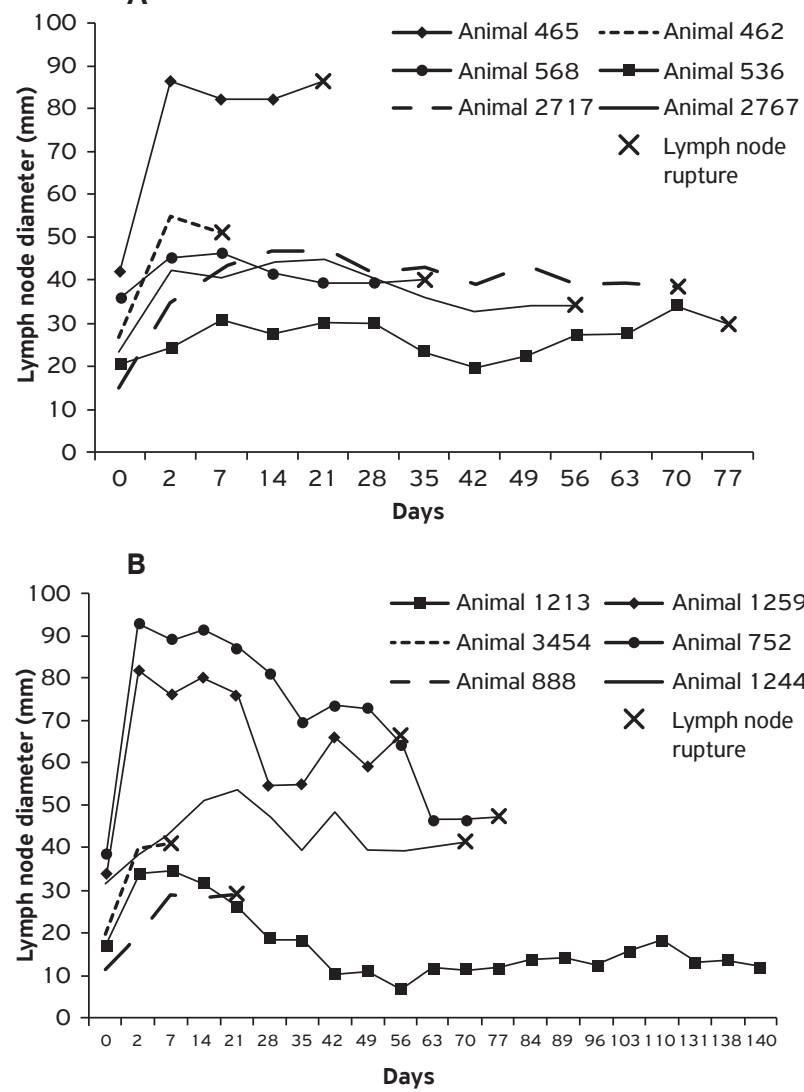

C

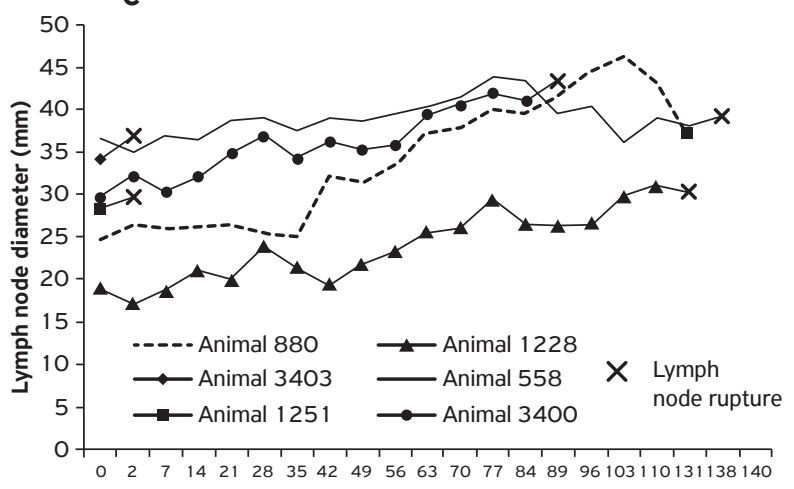

Days

Figure 1. Evolution of the diameter of lymph nodes of animals treated with iodine tincture at $10 \%(\mathrm{~A})$, animals treated with sodium hypochlorite at $2.5 \%$ (B) and animals belonging to the control group (C), over time. material, there was always confirmation of the agent. It is assumed that the quantity of product applied into the lymph nodes of these animals was not enough to cause the elimination of the microorganism over the full extension of the abscess.

As for the group treated with sodium hypochlorite at $2.5 \%$, spontaneous rupture was observed in 5 out of the 6 abscesses treated. In this case, C. pseudotuberculosis was isolated and identified in the injury of the five animals after rupture of abscess. The confirmation of the etiological agent of CL in the material inside the abscess, after its rupture, makes the use of this treatment impracticable, since this material represents the main source of infection of the disease over the herd. In the sixth animal from SH group, it was found the involution of abscess after treatment, whose diameter reduced to the same value as the contralateral normal lymph node. This result can be explained from analysis of diameter of abscesses of animals, obtained before treatments. The only animal whose lymph node showed regression in size after treatment owned an abscess in a very early stage of development, if compared to other animals. This should be taken into account in assessing the effectiveness of the suggested treatment, once the approach recommended for the treatment of any abscess in advanced stage is the complete draining of all the material formed (KNIGHT et al., 1980). It is suggested that, if the treatment had been done in an earlier period than the one described, i.e., in an earlier stage of development of abscesses, the results might prove satisfactory. However, if this hypothesis is actually confirmed in future studies, it is assumed that the practicability of the new treatment is compromised, once abscesses in extremely initial stage of development are unlikely to be detected only by periodic inspection of herd, but by monitoring through external palpation of lymph nodes of animals.

Another important factor which should be mentioned concerns the duration of the clinical presentation of the disease. It is observed that, 90 days after treatment, all animals in groups IT and SH did not act anymore as clinical carriers of the disease (Fig. 1A and B). At this time, all lesions in animals belonging to these two groups were already healed, unlike what was observed for animals in group CT, where the resolution of the inflammatory process is concentrated in the period between the $84^{\text {th }}$ and $140^{\text {th }}$ day of the experiment (Fig. 1C). The information above is confirmed after the evaluation of the average duration, in days, of the clinical phase of the disease. IT group had a duration average of 51.33 days, $\mathrm{SH}$ group took 52.5 days and CT group lasted 87.67 days, that is, one month more than the other treatments. Therefore, if it is conducted some type of adaptation causing it to become satisfactory, shortening the course of the disease would be one more advantage gained with the new technique. A shorter duration of clinical stage of the disease would lower spending on manpower, once after detection of lesions a more frequent monitoring of animals is necessary 
in order to prevent spontaneous rupture of abscesses and environmental contamination.

Figure 2 shows the percentage of efficacy of both treatments compared to the conventional, currently recommended for CL. Regarding the control of environmental contamination by $C$. pseudotuberculosis, note that the conventional treatment was more effective than the other two groups. It is important to say that it was considered as efficient, for IT and $\mathrm{SH}$ groups, as the treatment which promoted involution of abscess or, after spontaneous rupture of the nodule, did not contain viable C. psendotuberculosis in the lesion. As for the conventional treatment, the efficacy was determined according to the nonoccurrence of unexpected spontaneous rupture of abscess.

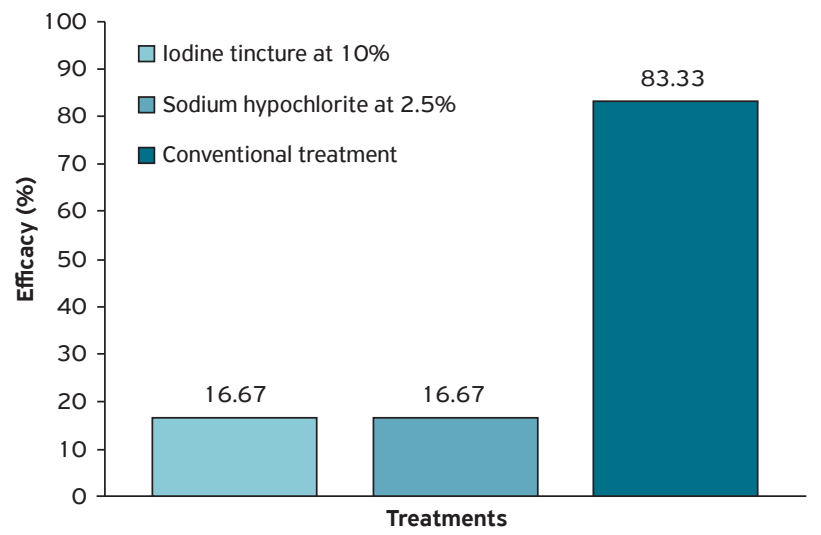

Figure 2. Efficacy (\%) of treatments with iodine tincture at $10 \%$, sodium hypochlorite at $2.5 \%$ and conventional treatment.
It is important to emphasise that sodium hypochlorite at $2.5 \%$ applied into lymph nodes of animals was responsible for pain reaction, differently from that observed for iodine tincture at $10 \%$. In addition, an edema was observed in the region of lymph nodes of animals belonging to both groups, formed shortly after the completion of the treatment. This fact can be explained by strong irritation caused by these products when used at high concentrations and in contact with living surfaces such as skin and mucous membranes (UFRGS, 2003). It is suggested, therefore, prior use of local anaesthetics, in case future studies will be done considering adaptations of this treatment. Except for one animal in group $\mathrm{SH}$, all abscesses treated progressed to rupture. In all cases, a lesion with exposure of the muscles in the region was formed, requiring a daily monitoring of animals over approximately seven days, until complete wound healing. Treatment of injuries after rupture was done with the application of iodine tincture at $10 \%$, after removal of all purulent material and insect repellent application. Only in one specific case, it was necessary to use antibiotic, healing ointment for treatment of wound, after a local secondary infection was detected through microbiological examination of the material collected.

The hematology average values obtained at the beginning and at the end of the experiment are described in Table 1. From data analysis, it was observed that all indexes were within normal limits for sheep, according to values provided by JAIN (1993). The comparative analysis between the

Table 1. Average values of haematocrit, haemoglobin, leucocytes and absolute averages of segmented neutrophils, band cells, lymphocytes and monocytes of animals in the groups treated with iodine tincture at $10 \%$, sodium hypochlorite at $2.5 \%$ and control group, in the initial (1) and final (2) months of the experiment.

\begin{tabular}{|c|c|c|c|c|c|}
\hline & \multicolumn{4}{|c|}{ Treatment } & \multirow[b]{2}{*}{ Normal values for sheep* } \\
\hline & Month & lodine tincture at $10 \%$ & $\begin{array}{c}\text { Sodium hypochlorite } \\
\text { at } 2.5 \%\end{array}$ & Control & \\
\hline \multirow{2}{*}{ Cell Volume (\%) } & 1 & $24.67^{\text {Aa }}$ & $25.17^{\text {Aa }}$ & $25.5^{\mathrm{Aa}}$ & \multirow{2}{*}{24 to 50} \\
\hline & 2 & $28.5^{\text {Aa }}$ & $27^{\mathrm{Aa}}$ & $28.5^{\text {Aa }}$ & \\
\hline \multirow{2}{*}{ Haemoglobin (g/dL) } & 1 & $9.6^{\mathrm{Aa}}$ & $8.95^{\mathrm{Aa}}$ & $9.6^{\mathrm{Aa}}$ & \multirow{2}{*}{8 to 6} \\
\hline & 2 & $8.83^{\mathrm{Aa}}$ & $8.53^{\mathrm{Aa}}$ & $8.58^{\mathrm{Aa}}$ & \\
\hline \multirow{2}{*}{ Leucocyte $(/ \mu \mathrm{L})$} & 1 & $11,025^{\text {Aa }}$ & $10,250^{\mathrm{Aa}}$ & $8,250^{A a}$ & \multirow{2}{*}{4,000 to 12,000} \\
\hline & 2 & $7,225^{\mathrm{Aa}}$ & $6,891.67^{\mathrm{Ab}}$ & $7,976.5^{\mathrm{Aa}}$ & \\
\hline \multirow{2}{*}{ Eosinophils $(/ \mu \mathrm{L})$} & 1 & $903.17^{\mathrm{Aa}}$ & $900.83^{\text {Aa }}$ & $818.92^{\mathrm{Aa}}$ & \multirow{2}{*}{0 to 1000} \\
\hline & 2 & $851.08^{\mathrm{Aa}}$ & $713.67^{\text {Aa }}$ & $783.75^{\mathrm{Aa}}$ & \\
\hline \multirow{2}{*}{ Segmented $(/ \mu \mathrm{L})$} & 1 & $6334.17^{\text {Aa }}$ & $5160.92^{\text {Aa }}$ & $4164^{\mathrm{Aa}}$ & \multirow{2}{*}{700 to 6,000} \\
\hline & 2 & $3545.67^{\text {Aa }}$ & $3621.75^{\mathrm{Aa}}$ & $4030.83^{\mathrm{Aa}}$ & \\
\hline \multirow{2}{*}{ Band Neutrophils $(/ \mu \mathrm{L})$} & 1 & $\mathrm{O}^{\mathrm{Aa}}$ & $31.25^{\mathrm{Aa}}$ & $33.75^{\mathrm{Aa}}$ & \multirow{2}{*}{ Rare } \\
\hline & 2 & $34.33^{\mathrm{Aa}}$ & $14.17^{\mathrm{Aa}}$ & $28.83^{\mathrm{Aa}}$ & \\
\hline \multirow{2}{*}{ Lymphocytes $(/ \mu \mathrm{L})$} & 1 & $3256.92^{\text {Aa }}$ & $3582.42^{\text {Aa }}$ & $2846.33^{\mathrm{Aa}}$ & \multirow{2}{*}{2,000 to 9,000} \\
\hline & 2 & $2532^{\mathrm{Aa}}$ & $2387.33^{A b}$ & $2469.75^{\text {Aa }}$ & \\
\hline \multirow{2}{*}{ Monocytes $(/ \mu \mathrm{L})$} & 1 & $514^{\mathrm{Aa}}$ & $574.58^{\mathrm{Aa}}$ & $387^{\mathrm{Aa}}$ & \multirow{2}{*}{ O to 750} \\
\hline & 2 & $211.75^{\mathrm{Ab}}$ & $154.75^{\mathrm{Ab}}$ & $239.5^{\mathrm{Aa}}$ & \\
\hline
\end{tabular}

Equal uppercase letters in the same row indicate there is no statistically significant difference, and equal lowercase letters in the same column indicate there is no statistically significant difference between values, according to Dunnett's test at $5 \%$ level of significance *JAIN (1993). 
two groups tested and the control group reveals that there is no statistically significant difference $(p>0.05)$ regarding the evaluated variables. Thus, it is assumed that the toxicity of the products used, pain reaction and stress from all treatments did not trigger changes in red blood cell or leucocyte profile of animals. The statistical comparison between the initial and final months of study showed a significant difference $(\mathrm{p}<0.05)$ in $\mathrm{SH}$ group for leucocytes, lymphocytes and monocytes, and for monocytes in IT group. The decrease of such values by the end of the experiment can be explained by the resolution of inflammation. It is noteworthy saying that, even though treatments have not provided $100 \%$ of efficacy, after obtaining data and information needed for this study, all injuries were properly treated until their complete healing. By the third month of observation, all animals in groups IT and SH already had their lesion completely healed, and the increased values of lymphocytes and monocytes observed in earlier time were probably due to local lymphadenopathy and to the proliferation of macrophages for removal of cellular debris during the recovery process (BusH, 1994; WillaRd et al., 1994).

It can be seen that changes in blood count described in this study are due, most likely, to the inflammatory process caused by C. pseudotuberculosis (Gameel; Tatour, 1974). Therefore, it is important to say that the absence of significant differences between the groups tested and the control group, besides the permanence of all hematologic values within the normal range for sheep, suppress the possibility of harm to animals in this respect, due to the treatments.

The serological monitoring of animals performed by SHI over the five following months after the completion of treatments is shown in Figure 3. It is possible to see a peak in the serological values of animals belonging to IT and $\mathrm{SH}$ groups, in the first month after treatment, different from that observed for the control group. After increase in serology of the two groups mentioned, such values remained

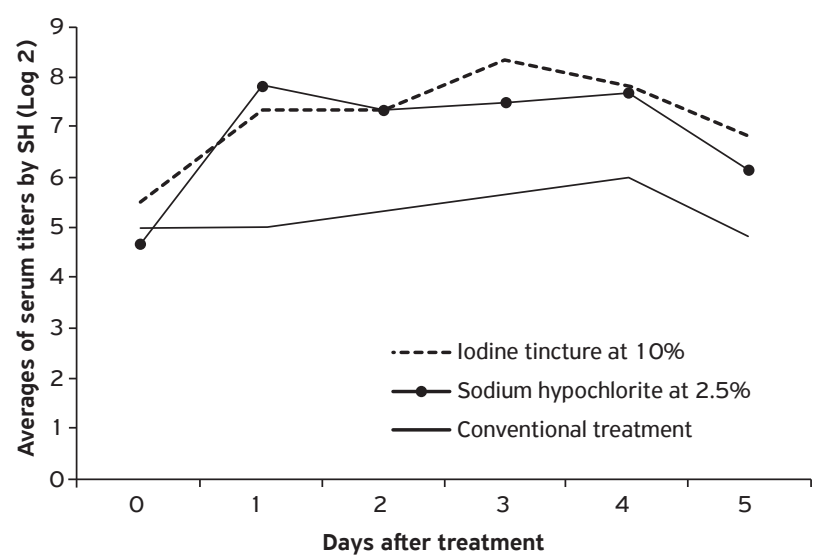

Figure 3. Averages of serum titers ( $\log 2$ ) by Serological monitoring of groups treated with iodine tincture at $10 \%$, sodium hypochlorite at $2.5 \%$ and the group under conventional treatment, over five months. relatively high until the fourth month. Thereafter, there was a slight fall in values. Moreover, it is observed that the serological titration of CT group remained constant throughout the experimental period.

The comparative statistical analysis between months, within each group, showed that months 1, 2, 3 and 4 are different $(\mathrm{p}<0.05)$ from month 0 for IT and SH groups (Table 2). In the CT group, there was no statistically significant difference between 1-5 months and month 0 , confirming what was concluded by the analysis of Figure 3. It is important to remember that $\mathrm{SHI}$ is a sensitive but not specific test, since it may indicate positive results from animals infected by other etiological agents as Staphylococcus aureus, Arcanobacterium pyogenes or others Gram positive bacillus (BRown et al., 1987). The absence of significant difference found for CT group could be justified by the low specificity of the test used in this experiment.

Bulgin (1998) describes the use of "autovaccine" by applying $10-25 \mathrm{~mL}$ of formalin (solution at $10 \%$ ) into the lymph node of animals affected by CL, with the caveat not to use it in animals intended for human consumption.

High values of serology against $C$. pseudotuberculosis found in this experiment for IT and SH groups, after the treatment, could be explained by the presence of viable bacteria cells in the lesion, inducing humoral immune response. The inflammatory reaction caused by the irritant action of iodine tincture at $10 \%$ and of sodium hypochlorite at $2.5 \%$ might also have stimulated cell migration, with greater exposure to antigens and, consequently, increased humoral immunity. It is worth mentioning that immune activity triggered against $C$. pseudotuberculosis is complex and involves both humoral response as well as cell response (Ellis et al., 1990). Hence the increase in serum titers of animals does not necessarily imply protection against re-infection or relapse of clinical symptoms. However, more detailed future studies aiming to test the

Table 2. Averages of serum titers $(\log 2)$ by Serological monitoring in groups treated with iodine tincture at $10 \%$, sodium hypochlorite at $2.5 \%$ and the group under conventional treatment, over five months.

\begin{tabular}{|c|c|c|c|}
\hline \multirow[b]{2}{*}{ Month } & \multicolumn{3}{|c|}{ Treatment } \\
\hline & $\begin{array}{c}\text { lodine tincture } \\
\text { at } 10 \%\end{array}$ & $\begin{array}{c}\text { Sodium hypochlorite } \\
\text { at } 2.5 \%\end{array}$ & Control \\
\hline $\mathrm{O}^{*}$ & $4.67^{a}$ & $5.50^{a}$ & $5.00^{a}$ \\
\hline 1 & $7.83^{b}$ & $7.33^{b}$ & $5.00^{a}$ \\
\hline 2 & $7.33^{b}$ & $7.33^{b}$ & $5.33^{a}$ \\
\hline 3 & $7.50^{b}$ & $8.33^{b}$ & $5.67^{a}$ \\
\hline 4 & $7.67^{b}$ & $7.83^{b}$ & $6.00^{a}$ \\
\hline 5 & $6.17^{a}$ & $6.83^{a}$ & $4.83^{a}$ \\
\hline
\end{tabular}

Equal lowercase letters in the same column indicate there is no statistically significant difference between values, according to Dunnett's test at $5 \%$ level of significance.

* Serology done before treatments of animals. 
suggested hypothesis and evaluate the possible protective effect of such products should be conducted.

\section{CONCLUSIONS}

It is concluded that the application of iodine tincture at $10 \%$ and sodium hypochlorite at $2.5 \%$ in the abscess of animals affected by the CL, in a development stage in which lesions are detected by inspection, is not $100 \%$ effective for controlling this disease.

Future studies should be carried out in order to evaluate the effect of the same treatment in animals which have not yet marked increase in lymph node, but already show a noticeable lymphadenopathy under palpation.

\section{ACKNOWLEDGEMENTS}

To Embrapa Goats and Sheep, for financial support and for having kindly provided the facilities and animals for this experiment. To FUNCAP and CNPq for financial support and provision of scholarships to students enrolled in the study.

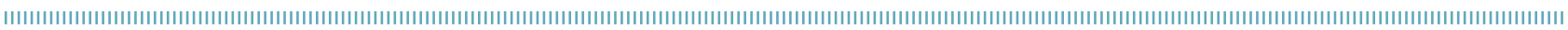
REFERENCES

ABNT - BRAZILIAN TECHNICAL STANDARDS ASSOCIATION. Solução de hipoclorito de sódio comercial - Determinação do teor de cloro ativo pelo método volumétrico. NBR 9425. Rio de Janeiro, 2005.

ALVES, F.S.F.; PINHEIRO, R.R. Controle da Linfadenite Caseosa pela aplicação de solução de formol no abscesso. Revista Brasileira de Medicina Veterinária, Rio de Janeiro, v.25, n.3, p.130-132, 2003.

ALVES, F.S.F.; SANTIAGO, L.B.; PINHEIRO, R.R. Linfadenite Caseosa: o estado da arte. Sobral: EMBRAPA Caprinos e Ovinos, 2007. 60p. (EMBRAPA-CNPC. Documentos, 74). Available from: <http://www.cnpc.embrapa.br/admin/ pdf/033204001201512.doc74.pdf.> Acessed on November, 72011.

BROWN, C.C.; OLANDER, H.J.; ALVES, F.S.F. Synergistic Hemolysis-Inhibition Titers Associated with Caseous Lymphadenitis in a Slaughterhouse Survey of Goats and Sheep in Northeastern Brazil, Canadian Journal of Veterinary Research, v.51, n. 1, p.46-49, 1987.

BROWN, C.C.; OLANDER, H.J. Caseous lymphadenitis of goats and sheep: a review. Veterinary Bulletin, v.57, p.1-12, 1987.

BULGIN, M.S. Central nervous disorders of sheep. In: SYMPOSIUM ON SMALL RUMINANTS FOR THE MIXED ANIMAL PRACTITIONER WESTERN VETERINARY CONFERENCE , I , 1998, Las Vegas. Proceedings... Las Vegas: 1998.

BUSH, B.M. Interpretation of laboratory results for small animal clinics. London: Blackwell Scientific Publications, 1994. 515p.

CARTER, G.R.; CLAUS, W.; RIKIHISA, Y. Essentials of veterinary bacteriology and mycology. 3.ed. Philadelphia: Lea \& Febiger, 1986. $261 \mathrm{p}$.

COLES, E.H. Patologia Clínica Veterinária. 4.ed. Rio de Janeiro: Saunders, 1993.
DIFFAY, B.C.; MCKENZIE, D.; WOLF, C.; PUGH, D.G. Abordagem e exame de ovinos e caprinos. In: PUGH, D.G. (Ed.). Clínica de ovinos e caprinos. São Paulo: Roca, 2005. cap. 1, p.1-19.

ELLIS, J.A.; HAWK, D.A.; HOLLER, L.D.; MILLS, K.W.; PRATT, D.L. Differential antibody responses to Corynebacterium pseudotuberculosis in sheep with naturally acquired caseous lymphadenitis. Journal of the American Veterinary Medical Association, v.196, n.10, p.1609-1613, 1990.

FIGUEIREDO, E.A.P.; SHELTON, M.; PANT, K.P. Goats skins. In: INTERNATIONAL CONFERENCE ON GOAT PRODUCTION AND DISEASE, 3., 1982, Tucson. Proceedings... Scottsdale: Dairy Goat Journal, 1982. p. 488-490.

GAMEEL, A.A.; TATOUR, G. Haematological and plasma protein changes in sheep experimentally infected with Corynebacterium pseudotuberculosis. Journal of Comparative Pathology, v.84, p.477-483, 1974.

JAIN, N.C. Essentials of Veterinary Hematology. Philadelphia: Lea \& Febinger, 1993, 417p.

JOIN-LAMBERT, O.E.; OUACHE, M.; CANIONI, D.; BERETTI, J.L.; BLANCHE, S.; BERCHE, P.; KAYAL, S. Corynebacterium pseudotuberculosis necrotizing lymphadenitis in a twelve-yearold patient. Pediatric Infectious Disease Journal, v.25, p.848$851,2006$.

KNIGHT, H.D. A serological method for the detection of Corynebacterium pseudotuberculosis infections in horses. Cornell Veterinary, v.68, n.2, p.220-237, 1978.

KNIGHT, H.D.; HIETALA, S.K.; JANG, S. Antibacterial treatment of abscesses. Journal of the American Veterinary Medical Association, v.176, n.10, p.1095-1098, 1980.

KRISHNA, L.; KULSHRESTHA, S.B.; PALIWAL, O.P. EpididimoOrchitis in ram due to Corynebacterium ovis. Indian Veterinary Journal, v.54, n.2, p.517-519, 1977. 
MILLS, A.E.; MITCHELL, R.D.; LIM, E.K. Corynebacterium pseudotuberculosis is a cause of human necrotising granulomatous lymphadenitis. Pathology, v.29, n.2, p.231233, 1997.

MORAES NETO, O.T.; RODRIGUES, A.; ALBUQUERQUE, A.C.A.; MAYER, S. Manual de capacitação de agentes de desenvolvimento rural (ADRs) para a Caprinovinocultura. João Pessoa: SEBRAE/ PB, 2003. 114 p. Available from: < http://www.biblioteca. sebrae.com.br /bds/BDS.nsf/5D12OF3826B6458A832 56F58006333A6/\$File/NTO00A1CF6.pdf>. Acessed on November, 72011.

NAIRN, M.E.; ROBERTSON, J.P. Corynebacterium pseudotuberculosis infection in sheep: role of skin lesions and dipping fluid. Australian Veterinary Journal, v.50, n.12, p.537342, 1974.

PATON, M.W.; ROSE, I.R.; HART, R.A.; SUTHERLAND, S.S.; MERCY, A.R.; ELLIS, T.M.; DHALIWAL, J.A. New infection with Corynebacterium pseudotuberculosis reduces wool production. Australian Veterinary Journal, v.7 1, n.2, p.47-49, 1994.

PATON, M.W.; WALKER, S.T.; ROSE, I.R.; WATT, G.T.; MERCY, A.R.; Prevalence of caseous lymphadenitis and usage of caseous lymphadenitis vaccines in sheep flocks. Australian Veterinary Journal, v.81, n.1/2, p.91-95, 2003.

PEEL, M.M.; PALMER, G.G.; STACPOOLE, A.M.; KERR, T.G. Human lymphadenitis due to Corynebacterium pseudotuberculosis: report of ten cases from Australia and review. Clinical Infectious Diseases, v.24, n.2, p.185-191, 1997.

SAEG - Sistema para Análises Estatísticas, Versão 9.1: Fundação Arthur Bernardes - UFV - Viçosa, 2007.

SANTIAGO, L.B.; ALVES, F.S.F.; PINHEIRO, R.R.; DOS SANTOS, V.W.S.; RODRIGUES, A.S.; CHAPAVAL, L.; DE BRITO. I.F.; DE SOUSA, F.G.C. Avaliação in vitro da sensibilidade da Corynebacterium pseudotuberculosis frente a diferentes tipos de antissépticos e desinfetantes e determinação de sua curva de crescimento. Arquivos do Instituto Biológico, São Paulo, v.77, n.4, p.593-600, 2010.

UNIVERSIDADE FEDERAL DO RIO GRANDE DO SUL. Comissão de Segurança-Cbiot. Produtos químicos de uso frequente no Cbiot. Available from: <http:www.ufrgs.br/cbiot/CS/CS_ Cbiot08.htm>. Accessed on October, 222003.

WILLARD, M.D., TVEDTEN, H., TURNVALD, G.H. Small animal diagnosis by laboratory methods. Philadelphia: W.B. Saunders Company, 1994. 377p.

WILLIAMS, C.S.F. Differential diagnosis of caseous lymphadenitis in the goat. Veterinary Medicine and Small Animal Clinician, v.75, n.7, p. $1165-1169,1980$.

WILLIAMSON, L.H. Caseous lymphadenitis in small ruminants. Veterinary Clinics of North America - Food Animal Practice, v. 17 , p.359-371, 2001. 